\title{
Kiállok érted! Színdarab és egyéb bünmegelőzési tevékenységek
}

I stand up for you! Play and other crime prevention activities

\author{
Barabás Ildikó \\ kiemelt föreferens, rendőr alezredes, \\ Országos Rendőr-főkkapitányság, \\ Bünügyi Főosztály, Bünmegelőzési Osztály \\ barabasi@orfk.police.hu
}

\begin{abstract}
Absztrakt
Cél: A cikkben a szerző a prostitúció veszélyeire felhívó színdarab bemutatására vállalkozik, amelyet szerte az országban bemutattak.

Módszertan: Az előadás és a hozzá kapcsolódó feldolgozó program elsősorban a prostituálttá válás és az emberkereskedelem veszélyének kitett fiatalok lehetőségeit, és az áldozattá válás folyamatát vizsgálja.

Megállapítások: Két, nevelőintézetből megszökött tinédzser lány, Kitty és Sunny történetét dolgozza fel, akik Szabolcs megyéből indulnak Hollandiába dolgozni, ahol prostitúcióra kényszerítik őket.

Érték: A tanulmány rávilágít arra, hogy a vonatkozó színdarab hogyan segíti és támogatja a gyermekotthonok lakóit a bünmegelőzés elősegítése érdekében.
\end{abstract}

Kulcsszavak: emberkereskedelem, prostitúció, rendőrség, bűnmegelőzés, áldozatsegítés

\begin{abstract}
Aim: In this article, the author undertakes to present a play about the dangers of prostitution that has been shown across the country.

Methodology: The performance and the related processing program focus on the opportunities for young people at risk of prostitution and trafficking in human being, and the process of becoming a victim.

Findings: It deals with the story of two teenage girls who escaped from a boarding-school, Kitty and Sunny, who leave Szabolcs County to work in the Netherlands, where they are forced into prostitution.
\end{abstract}


Value: The study highlights how the relevant play helps and supports residents of orphanages to promote crime prevention.

Keywords: trafficking in human beings, prostitution, police, crime prevention, victim support

\section{Bevezetés}

A világ országai, köztük Magyarország is évek óta egyre határozottabb fellépésre törekszik az emberkereskedelem ellen. Különféle stratégiákkal és tervekkel próbálják visszaszorítani, lehetőleg megelőzni ezt a jelenséget.

A rabszolgaság és az emberkereskedelem elleni tevékenységek világszerte négy pillére épülnek. Az angolszász szakirodalomban ezt „4 P”-nek nevezik (prevention, protection, prosecution, partnership/participation).

Magyarul prevenciónak/megelőzésnek, védelemnek, bünüldözésnek és együttmüködésnek/részvételnek nevezzük ezeket a pilléreket. Az együttműködés/részvétel valójában a másik három pillér szerves részét kell képezze, biztosítva az emberkereskedelem, modernkori rabszolgaság elleni küzdelem szereplői közti szakmai párbeszédet, eszmecserét, és a helyi, regionális vagy nemzetközi kezdeményezések összehangolt megvalósulását.

A rabszolgaság és emberkereskedelem mértékének csökkentésében a négy pillér párhuzamos fejlesztése hozhat igazán jelentős eredményt, de a prevenció szerepe kiemelten fontos ahhoz, hogy a potenciális áldozatok tájékozódjanak a veszélyekről és elkerülhessék azokat.

Évtizedekkel ezelőtt a külföldi szakemberek elsősorban a származási és célországokban folytatott kampányoktól várták a sérülékeny, veszélyeztetett csoportok szemléletformálásának sikerét. Mára sokkal szélesebb a megelőzésben alkalmazott tevékenységek köre, és egyre több tudományterület járul hozzá ezekhez.

A prevenciós tevékenységek megszólíthatják a veszélyeztetett, sérülékeny csoportokat, ugyanakkor szólhatnak a többségi társadalomhoz is, hogy jobb eredmények szülessenek a jelenség felismerésében, és több esetet jelentsenek a hivatalok felé.

Hazánkban virágzik az úgynevezett „loverboy” iparág, amelyet olyan férfiak müködtetnek, akik rendkívül jó külső adottságaikat, sármjukat, határozott fellépésüket vetik be a lányok felhajtása érdekében. Többen fizetést kapnak azért, hogy a diszkókat járva magukba bolondítsák a legszebb és legjobb mozgású lányokat. A lányok egykettőre belehabarodnak a „loverboyba”, aki kisvártatva felveti, költözzenek külföldre. Azzal a mesével áll elö, hogy jobb lesz nekik 
Nyugaton, ahol már várja is a munka, a lány otthon maradhat, mert úgyis hamarosan családot alapítanak. A lányok nagyrésze ezt el is hiszi (Barabás, De Coll, Mihalkó \& Toszeczky, 2019).

Az emberkereskedelem vonatkozásában viszonylag magas látenciáról beszélhetünk. Az áldozatok vagy félnek és nem mernek a hatóságokhoz fordulni, vagy nincsenek tisztában azzal, hogy ők maguk kizsákmányolás áldozatai. A rendőrség bünmegelőzési egységei számtalan program és kampány szervezésében, megvalósításában vesznek részt, emellett az érintett állomány képzésében is jelentős feladatokat látnak el. Az elmúlt néhány évben az Országos Rendőr-fókapitányság (ORFK) a Belső Biztonsági Alaphoz kapcsolódóan számos pályázatban vett részt akár főpályázóként, akár együttmüködő partnerként. Az egyik pályázat keretében kifejezetten azon szervezetek munkatársai részére tartott képzést, akiknek az emberkereskedelem áldozatai azonosításában, irányításában kell részt venniük. ${ }^{1}$ Mielőtt bővebben kitérnénk a rendőrség prevenciós tevékenységére, mindenképp beszélnünk kell az érintett áldozati körről (célcsoportról), és a jellemző vonásokról.

„A sértettek vonatkozásában továbbra is az alacsony iskolai végzettség és a munkanélküliség jellemzö, döntö többségük magyar állampolgár. Az esetükben a jellemzö ösztönzö erö a rövidtávú meggazdagodás ígérete, de emellett az emocionális okok is jelen vannak (az elkövetök szerelmet szinlelnek, közös jövöt vázolnak fel). A 18. életévet be nem töltött prostituáltak szinte kivétel nélkül intézeti nevelés alatt álltak, náluk a sértetté válásukhoz nagyban hozzájárult a könnyü pénzkereset igérete mellett a kötödési igényük.

A külföldön folytatott prostitúciós tevékenység egyre meghatározóbb. Olyan nök is vállalják a jobb megélhetés reményében, akik korábban Magyarországon nem üzték ezt a foglalkozást. A külföldön végzett prostitúció azért is népszerü, mert a hölgyek közvetlen környezete nem szerez tudomást arról, hogy milyen célból utaztak ki.

Manapság az internet gyakorlatilag mindenki számára hozzáférhetővé válik, az okostelefonok terjedésével pedig - amivel gyakorta még a legszegényebbek is rendelkeznek - napi 24 órában. Az utóbbi időben számos alkalommal jellemzö eset volt, hogy a kiskorú lány a különféle internetes oldalakon megismert barátjával szökött meg, akár külföldre is, majd az esetek egy részében az új barát által került kapcsolatba a prostitúcióval”. (TIP, 2017)2

Amint látjuk a magyar áldozatok többsége az ország társadalmi, gazdasági szempontból lemaradó területein él, és alacsony az iskolai végzettsége.

1 354/2012. (XII. 13.) Korm. rendelet az emberkereskedelem áldozatai azonosításának rendjéről.

2 2017. évi rendőrségi TIP jelentés. 
Számukra nem nehéz kecsegtetőnek tünő ajánlatokat tenni. Az emberkereskedőknek mindig sikerül olyan áldozatokat találniuk, akik a külföldi munkavállalás reményében hajlandók kockáztatni. Fontos tudatosítani az ilyen helyzetben lévő emberekben, hogy merjék felvállalni a helyzetüket, bízzanak a hatóságok munkájában, abban, hogy megfelelő segítséget és támogatást kapnak, valamint az őket kizsákmányolókat elfogják és felelősségre vonják.

Éppen ezért a rendörség kiemelt hangsúlyt helyez a prevencióra. Jelenleg a Belügyminisztérium finanszírozásával valósul meg a „,Kiállok érted!” címü színdarab országos bemutatása, amely egy komplex társadalomérzékenyítő és preventív program. Az emberkereskedelem elleni hatékony fellépés érdekében az ORFK nagyon jó kapcsolatot alakított ki a témában érintett civil szervezetekkel, köztük a Névtelen Utak Alapítvánnyal. A , Kiállok érted!’ címü színdarab az alapítvány közremüködésével valósult meg, így közös munkánk során felmerült, hogy az ORFK segítségével több helyen is be lehetne mutatni.

A külföldön vagy a hazai utcákon dolgozó prostituáltak nagy része állami nevelőotthonokból kerül ki. A szeretetéhes, kiszolgáltatott fiatal lányokat könynyen elcsábítják az erre szakosodott futtatók. Hogy a fiatalok minél tisztábban lássák, miért és mire kell nemet mondani, három szervezet életre hívta a „,Kiállok érted!" címủ színházi előadást.

Az előadás elkészítését egyéves kutatómunka előzte meg: szociális szakemberek bevonásával kutatták a fiatalkori prostitúció kialakulását, az áldozattá válás folyamatát. A visszajelzések alapján egyöntetüen megállapítható, hogy a történet nagyon valósághủ és hiteles, éppen ezért megrázó. A történet olyan lányokról szól, akik mélyszegénységben nőnek fel, durva és rideg környezetben ismerkednek a világgal, amelyben kevés szeretet és figyelem jut nekik. Olyan lányokról, akik jólétben szeretnének élni, bármi is az ára. Akik szeretetre és szerelemre vágynak.

A Láthatáron Csoport, a KV Társulat és a Névtelen Utak Alapítvány közös projektje a Norvég Civil Támogatási Alap gondozásában indulhatott el, és elsősorban nevelőotthonban élő fiataloknak szól. Valóság és mese határán, a kamaszok nyelvét használva mutatják meg, mi történik egy állami gondozott lánnyal, aki azt hiszi, a nagy szerelem toppant be az életébe.

Az előadás eredeti célja a gyermekotthonok gyermekei és környezetük, továbbá a velük foglalkozó szakemberek figyelmének felhívása a prostitúció és a szexuális kizsákmányolás veszélyeire - az áldozattá válás folyamatától egészen az emberkereskedelem müködéséig -, feltérképezve a témában érintett civil szervezeteket, és kidolgozva a hatékony segítségnyújtás és együttmüködés módszereit, a gyermekek számára drámafoglalkozások és a szakembereknek kerekasztal beszélgetések tartásával. 


\section{A történet rövid összefoglalója ${ }^{3}$}

Kitty és Sunny vonaton utazik Nyíregyházáról Budapestre. Az a tervük, hogy továbbmennek Hollandiába. Sunny épp most szökött egy gyermekotthonból. Kitty mesél neki Marlenkáról, a cigánylányról, akit jól megszorongatott az ördög, igencsak átvert a táltos paripán érkező szerelmes herceg, és a végén menekülnie kellett a varázsló kertjéből. Ahogy a vonat halad, úgy mosódik el mese és valóság határa. Kitty, Sunny és Marlenka története a színpadon találkozik, meséjük-valóságuk szegénységről, kiszolgáltatottságról, szeretethiányról és sorsszerüségröl beszél - és talán ad némi reményt.

\section{1. számú kép: Jelenet az elöadásból - Loverboy effektus}

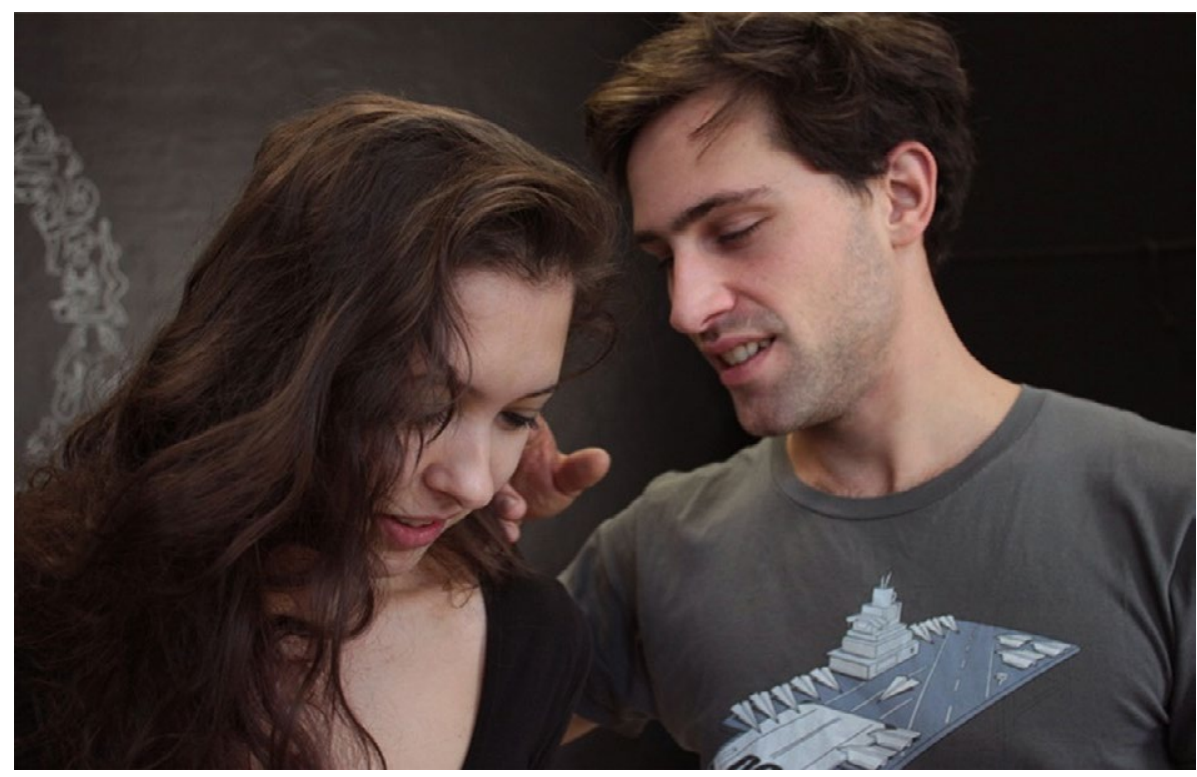

Forrás: A Láthatáron Csoport és a KV Társulat által készített előadásfotó a „Kiállok érted!” címü előadásból.

A színdarab kíméletlen hitelességgel tárja elénk a gyermekotthonokban nevelkedő, prostitúcióban érintett lányok sorsát, és környezetük reakcióit. A főszereplő már családjában is nélkülözéstöl, érzelmi elhanyagoltságtól, verbális és szexuális bántalmazástól szenved. Rövidesen belép a történetbe a futtató („,loverboy”),

3 A Láthatáron Csoport és a KV Társulat által készített „Kiállok érted!” kiajánló gyermekotthonos fiataloknak. 
aki kedvességekkel, ajándékokkal halmozza el áldozatát, majd rábírja a szökésre. A Nyírségből a fővárosba tartó vonaton megjelenik a középosztálybeli polgár archetípusa, aki nem is sejti az intézeti neveltek kiszolgáltatottságát. Jellegzetesnek mondható a gyermekotthon dolgozóinak alakja is, akik mindent megtennének a rájuk bízott gyermekekért, de a szexuális kizsákmányolás veszélyeivel szemben eszköztelennek bizonyulnak. Az utolsó jelenetben, a mindennapokban megfáradt kisember megbotránkozásán keresztül (felháborodás a lányok látszólagos jólétén: első osztályon utazás, márkás ruhák és drága ékszerek), az áldozathibáztatás jelensége is megjelenik.

\section{2. számú kép: Elöadásfotó}

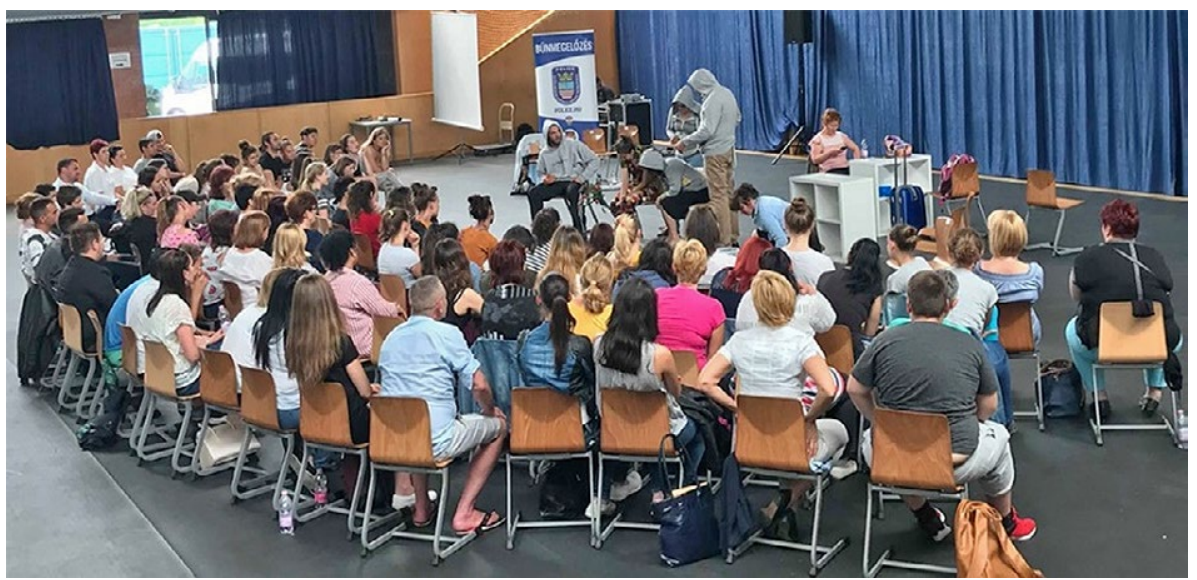

Forrás: Szerző saját készítése - Győr-Moson-Sopron megye, „Kiállok érted!” című előadás.

A színdarab - mint említettük - egy komplex társadalomérzékenyítő program, melyet a rendőr állomány részére mint érzékenyítő tréninget is elkezdtünk alkalmazni azzal a céllal, hogy segítsen számukra még közelebb hozni, megérteni a szexuális kizsákmányolás jelenségét, az áldozattá válás hátterét.

Mindemellett az emberkereskedelem, prostitúció jelenségének felhívására számos kezdeményezés volt a rendőrség „berkein belül” is, például általunk szervezett konferenciákon; a nők elleni erőszak megszüntetésének világnapja alkalmából szervezett szakmai napokon; kizsákmányolás megelőzéséről szóló fórumsorozatokon; gyermekotthonokban nevelkedő és onnan kikerülő személyek, valamint a középiskolai tanulók áldozattá válásának megelőzése érdekében tartott/tartandó bünmegelőzési előadásoknak témájaként; a külföldi munkavállalás veszélyei témában szervezett képzéseken. Továbbá a rendőrség által müködtetett Elektronikus Lakossági Bünmegelőzési Információs Rendszer 
(ELBIR) keretében rendszeresen ajánlás készül az emberkereskedelem, a külföldi munkavállalás és a prostitúció témájában.

\section{Megyei rendőr-főkapitányságok programjai a témában, a teljesség igénye nélkül}

\section{Biztos, hogy ezt akarod?!}

A Baranya Megyei Rendőr-főkapitányság munkatársai (Ambrus Zoltán és Pápai Balázsné) 2006-ban észlelték, hogy a Baranya megyei föutak mentén nagy számban árulják testüket a nők. Erre a jelenségre reagálva indult a „Biztos, hogy ezt akarod?!" című program. Célja a prostitúció és a hozzá kapcsolódó büncselekmények megelőzése. Ennek keretein belül az áldozattá válás szempontjából kiemelt kockázatú csoportok tagjai részére az oktatási intézményekben, gyermekotthonokban, lakásotthonokban felvilágosító tevékenységet folytattak. Az előadások témáit 2013-ban egészítették ki a külföldi munkavállalás veszélyei témakörrel. A program másik elemeként havonta visszatérően ellenőrizték az utak mellett prostitúciós tevékenységet folytató személyeket, részükre áldozatvédelmi tanácsadást nyújtottak. A témában részben kiadványt, részben a Matrioshki címü belga filmsorozatból (URL1) - egy olyan előadási anyagot készítettek, mely bemutatja, hogy az emberkereskedők hogyan szedik áldozataikat, hogyan kényszerítik a nőket prostitúcióra. A filmet igény szerint levetítik, a kiadványt átadják a diákoknak.

Ugyancsak a program részeként a prostituáltak részére is készítettek kiadványt, melyben arról tájékoztatják őket, hogy milyen szabályokat kell betartaniuk, továbbá baj esetén hogyan, és hol kérhetnek segítséget.

A Közfoglalkoztatottak vagyonbiztonságáért elnevezésű projekt a „Bünmegelözéssel a felzárkózásért" címü program tapasztalatai alapján indult. A Baranya Megyei Rendőr-főkapitányság munkatársai kezdeményezik a leghátrányosabb településeken történő felvilágosító tevékenységet. Témakörei: alapvető jogi tudnivalók és vagyonvédelem, kiegészítve a szülöi felelősség, kábítószerek, rendőri intézkedések, uzsorakölcsönök, prostitúció legfontosabb tudnivalóival. Az előadásokat minden településen a speciális igényekre szabják. A kompetenciaalapú és szakmai képzésekbe bekapcsolódó, valamint közfoglalkoztatásban részt vevő felnőtt és fiatal felnőtt korosztály áldozatvédelmi felvilágosítására 2014 óta kiemelt figyelem irányul a megyében. A cél a jogtudatosság erősítése, értékrend-korrekció, az áldozattá és bünelkövetővé válás megelőzése. A programban 2019-ig összesen 91 helyszínen - gyakran az Ormánságban - mintegy 
háromezer-egyszáz felzárkózásban érintett felnőttet és fiatal felnőttet szólítottunk meg a roma vezetők közremüködésével. A fogadtatás valamennyi településen rendkívül kedvező volt, minden megkeresett vezető élt a felajánlott lehetőséggel.

\section{Barishej}

A Debreceni MAM Tanácsadó Kft. a Hajdú-Bihar Megyei Rendőr-főkapitányság bevonásával indította el a Barishej (roma szó, jelentése: nagylány) elnevezéssel programját a hátrányos helyzetủ roma lányok iskolarendszerben tartása érdekében, melynek keretén belül húsz, halmozottan hátrányos helyzetü, 12-18 éves cigánylányt segít abban, hogy iskolai tanulmányaikat folytathassák. A program rendőrséget érintő része, hogy egy 18 alkalomból álló előadássorozattal segítse az érintetteket abban, hogy elkerüljék az áldozattá válást. Az előadássorozat külön kitér a külföldi munkavállalás, a prostitualizálódás és az emberkereskedelem témaköreire.

\section{Álom vagy rémálom}

A Veszprém Megyei Rendőr-főkapitányság Bünmegelőzési Osztálya a munkacélú kizsákmányolás megelőzésére a „Fókuszban a biztonság” bünmegelőzési projekt keretében „Álom vagy rémálom” címmel kidolgozott egy prevenciós programot.

A program a középiskolai kollégiumok 14-18 éves korosztályának szól. Témája a párkapcsolati erőszak, az interneten való ismerkedés, külföldi munkavállalás, és az ezzel kapcsolatos, a fiatalokra leselkedő veszélyekre történő figyelemfelhívás. Cél, hogy a fiatalok hiteles, naprakész ismereteket kapjanak e téren. Ennek érdekében aktuális, megtörtént, anonimizált eseteket is ismertetnek. A program időtartama kollégiumonként 55-75 perc.

Ennek keretében sor kerül egy filmvetítéssel színesített interaktív előadásra, illetve ezt követően - egy formabontó monológ keretében - egy drámapedagógiai szakember részvételével megtartott témafeldolgozásra. Ebben, a párkapcsolati erőszak tipikus jegyeit szemléltetve, a különféle szituációk színjátszásban is ismert módszereivel a fiatalok aktív közremüködésével dolgozzák fel a témát. Így lehetőség nyílik arra, hogy a fiatalok érzelmi hatások megélése révén hatékonyabban véssék be az információkat. Ezt egy közvetlen, a témát feldolgozó beszélgetéssel is segíti a drámapedagógiai szakember. A program végén lehetőséget adnak személyes tanácsadásra, konzultációra is. A programot a megye valamennyi kollégiumának kiajánlják írásban, a helyszíneket jelentkezések alapján választják ki. Említést érdemel, hogy a program sikeressége 
érdekében Vastag Tamás veszprémi kötődésü énekest is megnyerték, aki az internet biztonságos használatával kapcsolatos előadásaikat támogatta, és megjelenésével is segített a figyelem felhívásában.

\section{Hálozat-On}

A Pest Megyei Rendőr-főkapitányság Bünmegelőzési Osztály szervezésében a „Hálózat-On” címü színdarabot öt alkalommal mutatták be, közel 1000 fö diák részvételével, témája az emberkereskedelem, prostitúció, és a közösségi média használatának veszélyei. A színdarab megtekintését követően a diákok a darabot és annak témáját feldolgozó foglalkozáson vettek részt.

A „Hálózat-On” címü színpadi előadás első alkalommal a Biztonságos Internet Nap alkalmából, 2018. február 5-én került bemutatásra kortárs segítők közremüködésével. A darab a bizalomról és a netes ismerkedés veszélyeiről szól, melyet a Patkós Irma Müvészeti Iskola növendékei, Kroó Ádám rendező segítségével állítottak színpadra, Kiss Edit r. százados, a Pest Megyei Rendőr-főkapitányság Bünmegelőzési Osztály munkatársának forgatókönyve alapján.

3. számú kép: Internetes ismerkedés veszélyei

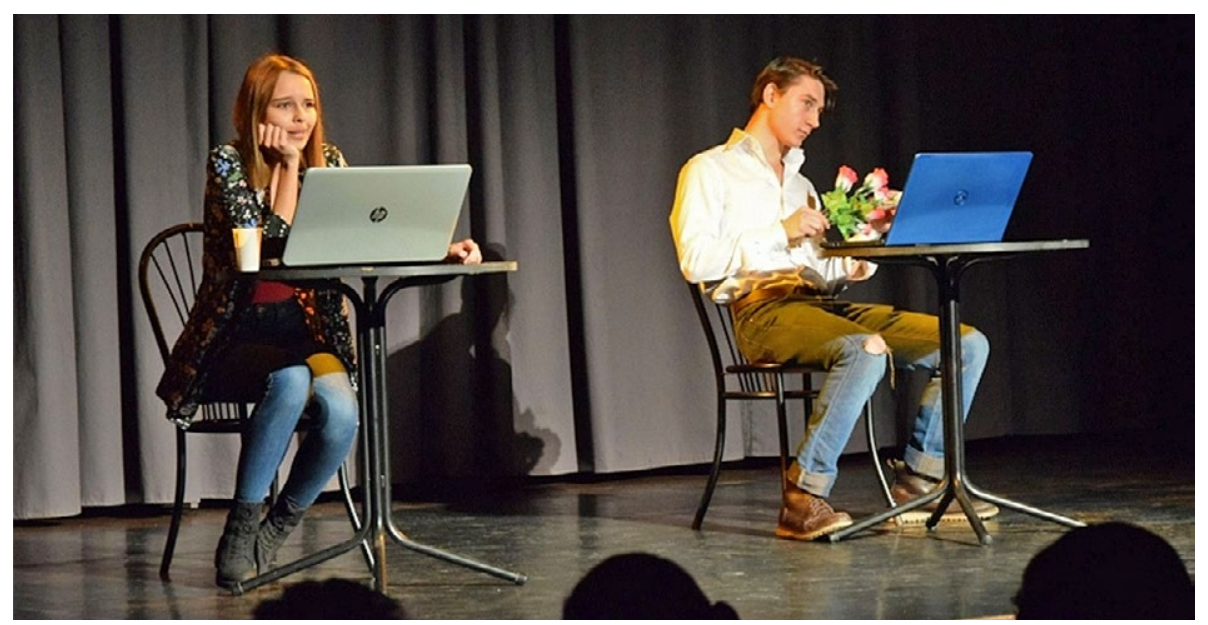

Forrás: Pest Megyei Rendőr-főkapitányság Bünmegelőzési Osztály munkatársai által készített előadásfotó - „Hálózat-On” című előadás.

Az előadást követően interaktív előadás formájában beszélték át a meghívott diákokkal a darabban is megjelenő online követés, a selfitis jelenség problémáit. A darab az internetes bünözést, az interneten elkövethető büncselekményeket 
dolgozta fel, egy lány történetét, aki egy szerelemnek induló eseménysorba csöppen bele az interneten keresztül, majd hiszékenysége miatt emberkereskedelem áldozata lesz.

\section{Következtetések}

Az emberkereskedelem, prostitúció tekintetében az áldozattá válás megelőzése továbbra is kihívást jelent mind az állami, mind a civil szféra számára az érintett kör jellemző vonásai miatt. Ahhoz, hogy ezen a területen a megelőzés megfelelően tudjon működni, egészen kormányzati szinttől a gyakorlati munka szintjéig továbbra is meg kell tenni a szükséges lépéseket. Ugyanakkor igazán jó hírnek számít, hogy ennek a jelenségnek a felszámolására igen kimagasló nemzeti összefogásnak lehetünk tanúi. Számos képzés, kerekasztal-megbeszélés, figyelemfelhívó kampány valósult meg az állami és a civil szféra együttmüködésében. A rendőrség bünmegelőzési szakemberei igyekeztek a bünmegelőzési eszköztárak széles körét használva eljuttatni üzeneteiket az érintett célcsoportnak. Azáltal, hogy a lakosság egyre szélesebb köre használja a közösségi médiát (Facebook, Instagram, Twitter) az információk sokkal gyorsabban és hatékonyabban jutnak el, reagálva az aktuális trendekre, problémákra.

\section{Felhasznált irodalom}

Barabás I., De Coll Á., Mihalkó V. \& Toszeczky R. (2019). A munkacélú kizsákmányolás megelözésének és az áldozatok segitésének lehetőségei. Készült a Pénzügyminisztérium és a Konszenzus Alapítvány Budapesti Szervezete között létrejött, a „Hosszú távú szolgáltatásfejlesztési szakértői tevékenység a munkacélú kizsákmányolás megelőzése érdekében” tárgyú, PM_SZERZ/116/2018 számú szerződés alapján a GINOP-5.1.1-15-2015-00001 és a VEKOP-8.1.1-15-2015-00001 „Út a munkaerőpiacra” kiemelt projekt keretében.

2017. évi rendőrségi TIP jelentés.

\section{A cikkben található online hivatkozások}

URL1: Matrioshki. https://port.hu/adatlap/film/tv/matrioshki-matroesjkas/movie-72135

\section{Alkalmazott jogszabályok}

354/2012. (XII. 13.) Korm. rendelet az emberkereskedelem áldozatai azonosításának rendjéről 


\section{A cikk APA szabály szerinti hivatkozása}

Barabás I. (2022). Kiállok érted! Színdarab és egyéb bűnmegelőzési tevékenységek. Belügyi Szemle, 70(2), 247-257. https://doi.org/10.38146/BSZ.2022.2.2 